\title{
The Impact of Teachers Professional Development in Video Technology on Mathematics and English Learning of Preschoolers in a Rural Primary School in Pakistan
}

\author{
Hamid Ikram \\ Dowling College, Oakdale, USA
}

\begin{abstract}
Learning media technologies are common and affordable tools in preschools for teaching and learning purposes. Unfortunately, many young children from low socio-economic communities do not have challenging and stimulating learning environment as compared to their advantaged peers. Moreover, the traditional teaching methods of mathematics and English language have failed because conventional methods of teaching miss the motivation factor. The classical methods are slower than the modern technical methods because the latter methods give students a more significant role in the learning process. Beside terrorism and corruption, the Pakistani education system suffers from many additional problems. In result, Pakistan's literacy rate remains one of the lowest in South Asian region. This developing mixed methods study intend to examine teachers' training to bring technological interventions in their nursery classrooms, and randomized controlled trials anticipate the effect of PBS and Sesame Street learning videos on 86 students' mathematics and English language learning.
\end{abstract}

\section{Introduction}

From the past century, both educators and researchers have been recongnizing that technology is becoming a vital need of young children. In 1922, Thomas Edison said that motion pictures would transform our educational system, and textbooks would be replaced with media technology. In 1945, William Levenson, Director of the City of Cleveland's public school radio station said that time might come when a portable radio receiver would be as common as a blackboard in the classroom. During the 1950s and into the early 1960s, B.F. Skinner argued that with the help of "teaching machines" students could learn twice as much as compared to traditional classroom methods [22]. In June 1997, at the National Education Computing Conference, Bill Gates encouraged teachers to use educational technology to boost students' success in the classroom [13].

Technology has always changed its modes and applications in different fields of life, including education. Since the establishment of instructional television, educational media such as videos, have been identified the useful medium of knowledge transfer. Over the decades, public televison has provdided numerous oppurtunities of distance education and professional development to K-12 educators. There was a time when public television was the most popular source of learning videos in $\mathrm{K}$ 12 classrooms. But now, most of the teachers have shifted their attention from public television to multimedia digital videos that are mostly available online [21]. In the modern world, video technology has become a vibrant and easily accessible tool used in the field of education [18].

Technology, of one type or other, has been a vibrant tool for teaching children for decades. Learning becomes meaningful when teachers are well trained and equipped to implement the technology-integrated curricula [26]. Thus, technology and media support young children's learning if technology is age appropriate, educationally unique in nature, and provided under the guidance of an adult [19]

Riley, Holleman, and Roberts [29] documented that technology yields positive results if it is engaged in school programs, and the future of education could be bright if educators retain technology in the system-it is vital for a school to integrate technology. Duttweiler and Madden [8] reported that technology is the key to success for the Friendship Independent School District in Texas, which serves more than 5,000 students. Similarly, in the Illinois public schools, Branigan [2] found a significant impact of using educational technology on student performance.

According to Reed [28], since January 2001, numerous schools have provided opportunities to their students for using videos on the Internet because the use of videos, aligned with the curriculum, in the classroom increase student 
achievement. [28] A recent survey of more than 1,000 parents of children age 2-6 revealed that parents want more media in the classroom, as 89 percent of parents agree that media can help to educate their kids [32]. Due to the demand of the digital nature of videos, many public television stations have partnered with local educators to support classroom instruction [21].

Unfortunately, teachers in low-income communites usually have less opportunities for professional training and have limited access to educational resources to prove their effectiveness. Such teachers can help their students to learn better if they have resources and tranings to effectively integrate learning media such as videos in the curriculum [26]. Nomass [20] stated that the academic institutions should bring modern technological equipment and laboratories to expediate the teaching process. Educational media technologies such as videos, photographs, games, and animation can be used to make learning more tangible. Penuel et al. [26] found that pre-school children, especially those from low-income families, develop early literacy skills if they experience media-rich curriculum that includes educational vidoes.

In today's world of the Internet, there are numerous platforms (Youtube, TeacherTube, Academic Earth, MIT Open Courseware, YouTube Edu, PBS Learning Media, Khan Academy, unitedstreaming ${ }^{\mathrm{TM}}$, Neweggs) that mostly offer thousands of free streaming educational videos for every class. Such platforms provide versatile, accessible, and affordable videos to the teachers to engage their students in learning, energize classroom discussion, and meet course-learning goals. The benefit of online videos is that they can be reused and replayed. Also, video clips could have a role as either a beginning or ending of instruction or a class session [1], [28] The digital form of videos provides the opportunity to interactively control video functions such as play, pause, stop, or repeat [18].

Since, the delivery method of educational videos has been changed from broadcasting to short digital video clips, teachers can now infuse video clips in their Microsoft PowerPoint presentations, traditional lectures, and electronic reports. Although, short video clips usually lack the context of the lesson, and sometimes such clips are not directly aligned with pedagogical and instructional context, teachers can assemble such raw material and use them in the classroom [21], [28]. Bonk [1] surveyed 1,000 participants and found that short videos of 1-4 minutes duration are ideal for learners, and leaners prefer humorous, informative, current, interesting, and engaging videos.

There are series of studies by PBS and public television stations to help teachers to locate, use, and incorporate videos in instruction [25]. Nugent [21] discussed that teachers need learning media be organized by subject area and grade level so they can search by keywords. Also, teachers want such platforms which can easily be controlled and deliver content according to students' needs. Likewise, the Web-Based Education Commission Report also highlighted the importance of easily accessible and standardized videos that should be aligned with learning needs [14].

Conversely, some researchers found little or no impact of videos on students learning [15]. Some research studies argued that videos are less effective for students' learning as compared to text [34]. However, according to Bonk [1], videos provoke students' interest in the topic when embedded in the instruction, and video technology will spread its horizon and will find its role in teaching and learning in this century.

\section{Purpose}

There is a common assumption that students watch videos, such as cartoons, only for entertainment and fun. This study evaluated that educational videos could also be used for learning purposes. In rural areas in Pakistan, students from low-income families have very limited academic resources at home and they do not have the opportunity to watch videos and television. This study created a learning community, embedded with entertainment, in which students were engaged with their peers, watched multiple videos, enhanced by games, about basic mathematical and English language skills.

The purpose of this mixed methods study was to examine the effect of teachers' professional development in video technology (PBS \& Sesame Street videos) on mathematics and English language learning among preschool students in the rural area of Pakistan where it was impossible for students to experience watching videos for learning purposes. This study assessed teachers' motivation and frustration, before and after professional development, towards the use of video technology in the classroom. Finally, the demographics of gender, socioeconomic status of the students, parents' education/occupation, learning resources at home for children, and the use of technology and media at home were contrasted to examine how they affect students learning of mathematics and English.

\section{Theoretical Framework}

Recently, early childhood education has become the center of attention for educators and researchers because it is believed that the greatest benefit to the human capital could be realized by improving the early education of young children [12]. Educators are 
looking for different techniques to improve the quality of early education programs, specifically in the field of mathematics and literacy [35]. The researchers found that high-quality learning experiences for students at early grades result in better performance in higher grades [5].

Educational technology including learning media has revolutionized the teaching and learning process of every grade level and every course level including mathematics and English. Learning media technologies can foster learning among children if they are age appropriate and promote active engagement [26]. Moreover, media technologies are common and affordable tools in preschools for teaching and learning purposes [23]. Videos, photographs, games, and animations are the most common examples of the learning media.

Learning becomes more tangible when students experience visualization of the content. Ross and Schulz [30] asserted that concepts could be easily transferred to students through videos as compared to motionless textbook illustrations. Reed [28] found that the use of educational videos in the classroom increase students' achievement significantly. Syed [33] claimed that videos are the powerful, expressive tools that provide multi-sensory learning opportunity to learners to learn and retain the information. Similarly, Fox [10] inquired that videos stimulate students' episodic memory to retain the information for a longer period of time.

Many young children from low socio-economic communities do not have challenging and stimulating learning environments as compared to their advantaged peers [11]. As a result, there is a big achievement gap among children living in lowresource communities and children living in higherresource communities [31]. Riley, Holleman, and Roberts [29] asserted that all children should have equal access and opportunities to use technology for learning purposes. Raudenbush [27] stated that highquality and media enriched experiences, at early levels of education, assist children from low SES communities at a higher rate because they do not have such opportunities at home, and usually their parents have less formal education [3]. In addition, numerous research studies have proven that the preschool children, especially from low-income families, develop early literacy, reading, and mathematics skills, if they experience media-rich curriculum that includes educational videos and games [24], [26].

The early age of children, especially form underresourced communities, is important for learning, as they are capable of developing literacy and numeracy skills at this age and these skills can be achieved in two different settings: home and school [23], [24]. Researchers have found that early achievement in mathematics leads to later school achievement (Clements \& Sarama), and early mathematical skills are stronger predictors of later school achievement as compared to early literacy and socio-emotional development [6], [9].

Researchers found that most of the preschool teachers are not well trained to use multiple teaching strategies, nor are they able to align their instructions with the developmental course of young children (Ginsburg, Lee, \& Boyd). According to the National Education Association, at least 50 percent of today's teachers do not have proper training and support required to incorporate technology and media into the instruction [11].

English and mathematics courses are taught as a subject in state-controlled schools in Pakistan, starting at the nursery level, but Pakistan's literacy rate remains one of the lowest in south asian region. Beside terrorism and corruption, the Pakistani education system suffers from many additional problems: insufficient financial input, high drop-out rate, lack of motivation among students and teachers, poor implementation of programs, low quality management, and less opportunities for teachers' professional development [16], [17].

There is not much research done using randomized controlled trials to test specific curriculum to see the casual relationship between curriculum and child outcomes in low-income populations [4]. The gains from early quality experiences are not guaranteed. Thus, more research is needed to test the curriculum interventions in early education programs [7].

This mixed methods study will examine teachers' training to bring technological interventions in their classrooms and randomized controlled trials will measure the effect of PBS and Sesame Street learning videos on students' mathematics and English language learning. The researcher will train teachers to use learning videos (PBS and Sesame Street) to incorporate into their teaching. The researcher will help teachers to create video-based lessons with the help of Frame, Focus, Follow-up (FFF) guidelines developed by EDC's Center for Children and Technology and Thirteen/WNET New York.

\section{Research Questions}

In the pursuit of study goals, this proposed study will answer the following research questions.

\subsection{Research question one}

How do teachers describe their motivation and frustration using the instructional technology specifically video technology in the classroom before and after the experiment? How do they see their motivation or frustration using video technology after the experiment? 


\subsection{Research question two}

What are the baseline test and competency scores of the students of English and mathematics?

\subsection{Research question three}

What is the difference in the growth index on family demographics: gender, SES, parents' education and occupation, learning resources at home for children, and the use of technology and media at home?

\subsection{Research question four}

What is the growth index in learning numeracy for pre-k elementary students using videos and not using videos for learning mathematics?

\subsection{Research question five}

What is the growth index in learning alphabet for pre-k elementary students using videos and not using videos for learning English?

\subsection{Research question six}

What is the achievement difference between technology and media experience on young children's mathematics learning and in a traditional class?

\subsection{Research question seven}

What is the achievement difference between technology and media experience on young children's English language learning and in a traditional class?

\section{Methodology}

This mixed methods case study will include teachers' professional development using media technology in the classroom and the researcher will record teachers' motivation and frustration towards using instructional technology specifically video technology. Also, this study will consist of experimental series using video-technology for students' mathematics and English language learning. Figure 5.3.1 and 5.3.2 elaborates the pictorial form of the research design proposed for this study.

\subsection{Participants}

This study will include all nursery students (boys and girls) of a rural primary school in the Punjab province in Pakistan, after parents have given their consent. The researcher will split the classroom into two equal but random groups, i.e., control group and experimental group. With the help of table of randomization, the researcher will randomly assign students into equally-sized experimental and control groups of mathematics and English. The experimental group will have the opportunity for watching videos for learning, while the control group will have instruction as usual. To consider the ethical requirements, students in mathematics experimental group will be in the English control group and viceversa.

Two teachers are part of this study, i.e. one teaching mathematics and the other teaching English at the nursery level in that school. They volunteer to be part of this study and willing to take professional development and technology training. The training will be unpaid, as teachers have volunteered for the training, inside the school building.

\subsection{Instrumentation}

Students in the experimental and control group of mathematics course will be pre-tested and post-tested through a researcher's developed test, based on the standardized test called Research-Based Early Mathematics Assessment (REMA) developed by Clements et al. [5] From the pool of 199 items of REMA, the researcher will pick and modify 13 items to assess nursery students' mathematics learning. With the help of teachers, the researcher will pre-test and post-test control and experimental groups of students in English course by converting mathematics items, adopted by REMA, into English items. However, the English test will include nine items.

Teachers will be pre-interviewed and postinterviewed by the researcher, before and after the experiment, through a researcher made semistructured interview protocol consisted of nine openended questions supported by probes.

\subsection{Procedures}

During the first phase of this study, the researcher will develop video-based lesson plans with teachers, and train them professionally to incorporate learning videos in their curriculum. To develop the lesson plans, the idea of Frame, Focus, Follow-up strategy, introduced by Thirteen/WNET New York, for effective video-based lessons will be used. The purpose of such training is to help teachers understand how to use media technology for their instruction.

During the second phase of this study, teachers teaching to the experimental group will incorporate 
learning media (PBS and Sesame Street videos) into their instruction. From the DVDs of PBS and Sesame Street on numeracy and alphabet the researcher will facilitate teachers to choose short video clips (2-4 minutes), which are aligned with their curriculum, and that are culturally appropriate for the students.

Teachers will be informed that they will use videos at least twice a week. They will keep a record of how many times videos were used during the week. The researcher will be in the school premises to help with technical problem, but would not interfere with the class.

Table 1. Research Design Math

\begin{tabular}{|c|c|c|c|c|c|}
\hline $\begin{array}{c}\text { Math } \\
\text { Teacher } \\
\text { Pre- } \\
\text { interview } \\
\end{array}$ & $\begin{array}{c}\text { Professional } \\
\text { Development } \\
\text { (2 weeks) }\end{array}$ & & \multicolumn{3}{|c|}{$\begin{array}{l}\text { Experimental Phase } \\
\quad(8 \text { weeks) }\end{array}$} \\
\hline $\mathrm{X}$ & $\mathrm{O}$ & & \multicolumn{3}{|c|}{ Math Experimental Group } \\
\hline & & $\begin{array}{c}\text { Classroom } \\
\text { 1- Math } \\
\text { Teacher } \\
\end{array}$ & $\begin{array}{l}\text { Pre-test } \\
\text { (Students) }\end{array}$ & Treatment & $\begin{array}{l}\text { Post-test } \\
\text { (Students) }\end{array}$ \\
\hline & & & $\mathrm{X}$ & $\mathrm{O}$ & $\mathrm{X}$ \\
\hline & & & \multicolumn{3}{|c|}{ Math Control Group } \\
\hline & & $\begin{array}{c}\text { Classroom } \\
2 \text { - Math } \\
\text { Teacher }\end{array}$ & $\begin{array}{c}\text { Pre-test } \\
\text { (Students) }\end{array}$ & Treatment & $\begin{array}{c}\text { Post-test } \\
\text { (Students) }\end{array}$ \\
\hline & & & $\mathrm{X}$ & & $\mathrm{X}$ \\
\hline & & & & & $\begin{array}{c}\text { Math } \\
\text { Teacher } \\
\text { Post- } \\
\text { interview }\end{array}$ \\
\hline & & & & & $\mathrm{X}$ \\
\hline
\end{tabular}

Table 2. Research Design English

\begin{tabular}{|c|c|c|c|c|c|}
\hline $\begin{array}{c}\text { English } \\
\text { Teacher } \\
\text { Pre- } \\
\text { interview }\end{array}$ & $\begin{array}{c}\text { Professional } \\
\text { Development } \\
\text { (2 weeks) }\end{array}$ & & \multicolumn{3}{|c|}{$\begin{array}{l}\text { Experimental Phase } \\
\text { (8 weeks) }\end{array}$} \\
\hline $\mathrm{X}$ & $\mathrm{O}$ & & \multicolumn{3}{|c|}{ English Experimental Group } \\
\hline & & $\begin{array}{c}\text { Classroom } \\
2- \\
\text { English } \\
\text { Teacher } \\
\end{array}$ & $\begin{array}{c}\text { Pre-test } \\
\text { (Students) }\end{array}$ & Treatment & $\begin{array}{l}\text { Post-test } \\
\text { (Students) }\end{array}$ \\
\hline & & & $\mathrm{X}$ & $\mathrm{O}$ & $\mathrm{X}$ \\
\hline & & & \multicolumn{3}{|c|}{ English Control Group } \\
\hline & & $\begin{array}{c}\text { Classroom } \\
1- \\
\text { English } \\
\text { Teacher } \\
\end{array}$ & $\begin{array}{c}\text { Pre-test } \\
\text { (Students) }\end{array}$ & Treatment & $\begin{array}{l}\text { Post-test } \\
\text { (Students) }\end{array}$ \\
\hline & & & $\mathrm{X}$ & & $\mathrm{X}$ \\
\hline & & & & & $\begin{array}{c}\text { English } \\
\text { Teacher } \\
\text { Post- } \\
\text { interview }\end{array}$ \\
\hline & & & & & $\mathrm{X}$ \\
\hline
\end{tabular}

\subsection{Data Analysis}

The Statistical Package for the Social Science (SPSS), and Nvivo software will be used to perform data analyses. However, all respondent identities will remain confidential.

Researcher will conduct descriptive analysis, independent sample $t$-test one-way ANOVA for quantitative analysis. To identify patterns in teachers' qualitative responses during interviews, the researcher will examine all open-ended questions to develop potential coding categories. Open-ended responses will be coded to identify the meaningful themes, patterns, and discrepancies that will inform findings.

\section{Significance}

In Pakistan, public education system is dealing with many gigantic problems that includes: low quality trainig for teachers, low students enrolement, high drop-out rate at primary level, financial crisis, terrorism, and less technical facilities [16]. Such problems has not only frightened studnets but also demotivated teachers twoards their teaching profession. This study will motivate and guide teachers to use video technology for the teaching and learning process to enhance mathematics and English literacy at the preschool level. This present study will not only enhance students learning, but will also encourage teachers to continue their work. This study will provide an opportunity to teachers to replace their traditional teaching methodologies, mainly lectures, into more interactive and student engaged activities.

Below is the 12-week timeline for the implementation of this study, which will start with the teachers training in phase I. Later, phase-II will include experimentation of learning videos in the mathematics and English classrooms. Table 3 shows the summary of week of all the activities that will take place during the data collection period.

Table 3. Study Implementation and data collection schedule by week

\begin{tabular}{|l|l|l|l|l|}
\hline \multicolumn{1}{|c|}{ Week } & \multicolumn{1}{|c|}{1} & \multicolumn{1}{c|}{$2-3$} & \multicolumn{1}{c|}{$4-11$} & \multicolumn{1}{c|}{12} \\
\hline $\begin{array}{l}\text { Teachers } \\
\text { Professional } \\
\text { Development }\end{array}$ & $\begin{array}{l}\text { Pre- } \\
\text { Interview } \\
\text { and } \\
\text { Tech- } \\
\text { Installation }\end{array}$ & $\begin{array}{l}\text { Teacher's } \\
\text { Training } \\
\text { (PD)/ } \\
\text { Lesson } \\
\text { Plan }\end{array}$ & $\begin{array}{l}\text { Implementa } \\
\text { tion } \\
\text { Observatio } \\
\text { ns }\end{array}$ & $\begin{array}{l}\text { Post- } \\
\text { Interview } \\
\text { and Tech- } \\
\text { Redistribu } \\
\text { tion }\end{array}$ \\
\hline $\begin{array}{l}\text { Mathematics } \\
\text { Experimental } \\
\text { Group-I }\end{array}$ & & Pre-Test & $\begin{array}{l}\text { Treatment } \\
\text { (Teaching } \\
\text { with } \\
\text { Videos) }\end{array}$ & $\begin{array}{l}\text { Post-Test } \\
\text { and }\end{array}$ \\
\hline $\begin{array}{l}\text { English } \\
\text { Control } \\
\text { Group-I }\end{array}$ & & Pre-Test & $\begin{array}{l}\text { Business } \\
\text { as Usual }\end{array}$ & Post-Test \\
\hline $\begin{array}{l}\text { English } \\
\text { Experimental } \\
\text { Group-II }\end{array}$ & & Pre-Test & $\begin{array}{l}\text { Treatment } \\
\text { (Teaching } \\
\text { with } \\
\text { Videos) }\end{array}$ & Post-Test \\
\hline $\begin{array}{l}\text { Mathematics } \\
\text { Control } \\
\text { Group-II }\end{array}$ & & & $\begin{array}{l}\text { Business } \\
\text { as Usual }\end{array}$ & Post-Test \\
\hline
\end{tabular}

\section{Future Research}

This proposed study could be conducted on different population, sample, ethnic group, grade level, and curriculum. The duration of the treatment could be increased and other conditions could be introduced in future researches. In addition to that, more assessment tools of early learners could be created and tested in such studies to see the reliability and validity of such instruments. The role 
of professional development in early learning environments is also an area that could be expanded in the future research to see which approach of professional development is most effective for teachers serving students who are at riskacademically. In the future researches, other technological tools and learning media sources could be tested for early learners. Future researches in this area could benefit early learners as well as their teachers to cope with the challenges of education they may face.

\section{Conclusions}

This proposed research study is limited to preschool level mathematics and English courses in a rural primary school in the Punjab province in Pakistan. This study is also limited to the teachers teaching mathematics and English courses at the preschool level in the same school. The duration of the treatment is 8 -weeks rather than a year long. The study will focus on those concepts of mathematics and English courses, which are required to be covered in the first two months in that particular school. Also, the sample of the study will not represent the preschool children of a whole province or country. According to school officials, there are no standardized tests used to measure the mathematics and English language learning of young children; however, the researcher's developed validated instruments to be used. As the researcher will not independently measure teachers' attitude and beliefs about the use of video technology in the classroom, information about their motivation and frustration with video technology will be gathered through interviews. The total duration of this proposed study is 12 weeks, including 2 weeks for teachers' professional development (PD), and 8 weeks for students' teaching experiment. The time required by teachers to become experts in using video technology in the classroom and the longrange impact of the two-week training program is not known.

\section{References}

[1] Bonk, C. J. (2008, March). YouTube anchors and enders: the use of shared online video content as a macrocontext for learning. Paper presented at the American Educational Research Association (AERA) 2008 Annual Meeting, New York, NY.

[2] Branigan, C. (2000). New study: technology boosts student performance. eSchool News Online. October.

[3] Brooks-Gunn, J. (2003). Do you believe in magic? What we can expect from early childhood intervention programs. Social Policy Report, 17(1), 3-14.
[4] Clements, D. H., \& Sarama, J. (2002). Mathematics curricula in early childhood. Teaching Children Mathematics, 9, 163-166.

[5] Clements, D. H., \& Sarama, J. (2008). Experimental evaluation of the effects of a research-based preschool mathematics curriculum. American Educational Research Journal, 45, 443-494.

[6] Clements, D. H., \& Sarama, J. H. (2009). Learning and teaching early math: the learning trajectories approach. New York, NY: Routledge.

[7] Clements, D. H., Sarama, J., Spitler, M. E., Lange, A. A., \& Wolfe, C. B. (2011). Mathematics learned by young children in an intervention based on learning trajectories: A large-scale cluster randomized trial. Journal for Research in Mathematics Education, 42(2), 127-166.

[8] Duttweiler, P. C., \& Madden, M. (2001). The district that does what's best for kids: Frenship isd. National Dropout Prevention Center.

[9] Duncan, G. J., Dowsett, C. J., Claessens, A., Magnuson, K., Huston, A. C., Klebanov, P., Pagani, L., Feinstein, L., Engel, M., Brooks-Gunn, J., Sexton, H., Duckworth, K., \& Japel, C. (2007). School readiness and later achievement. Development Psychology, 43(6), 14281466.

[10] Fox, G. (2003). Teaching normal development using stimulus videotapes in psychiatric education. Academic Psychiatry, 27, 283-288.

[11] Ginsburg, H. P., Lee, J. S., \& Boyd, J. S. (2008). Mathematics education for young children: What it is and how to promote it. Social Policy Report: giving Child and Youth Development Knowledge Away, 22(1), 3-22.

[12] Heckman, J. J. (2000). Policies to foster human capital. Research in economics, 54(1), 3-56.

[13] Howell, D. (2001). Elements of effective e-learning: three design methods to minimize side effects of online courses. College Teaching , 49 (3), 87-90.

[14] Kerrey, B., \& Isakson, J. (2000). The power of the Internet for learning: moving from promise to practice. Web-Based Education Commission. Washington, D.C. Retrieved on February 02, 2015 from http://portal.bigchalk.com/i/corp/edpolicy/editedwebcomm ission.pdf

[15] Mbarika, V.W., Sankar, C.S., Raju, P.K., \& Raymond, J. (2001). Importance of learning-driven constructs on perceived skill development when using multimedia instructional materials. The Journal of Education Technology Systems, 29(1), 67-87.

[16] Memon, G. R. (2007). Education in Pakistan: the key issues, problems and the new challenges. Journal of Management and Social Sciences, 3(1), 47-55.

[17] Memon, G. R., Joubish, M. F., \& Khurram, M. A. (2010). Education in Pakistan: the key issues, problems 
and the new challenges. Middle-East Journal of Scientific Research, 6(6), 672-677.

[18] Merkt, M., Weigand, S., Heier, A., \& Schwan, S. (2011). Learning with videos vs. learning with print: the role of interactive features. Learning and Instruction, 21, 687-704.

[19] National Association for the Education of Young Children \& Fred Rogers Center For Early Learning and Children's Media at Saint Vincent College. (2012). Technology and interactive media as tools in early childhood programs serving children from birth through age 8. Retrieved on January 01, 2014 from http://www.naeyc.org/files/naeyc/file/positions/PS_technol ogy_WEB2.pdf

[20] Nomass, B. B. (2013). The impact of using technology in teaching english as a second language. English Language and Litrature Studies, 3 (1), 111-116.

[21] Nugent, G. C. (2005). Use and delivery of learning objects in $\mathrm{K}-12$ : the public television experience. TechTrends, 49(4), 61-66.

[22] Oppenheimer, T. (1997). The computer delusion. The Atlantic Monthly, 280 (1), 45-62.

[23] Pasnik, S., \& Llorente, C. (2012). EDC/SRI year 2 ready to learn research and evaluation summary report: $a$ report to the CPB-PBS ready to learn initiative. Education Development Center and SRI International.

[24] Pasnik, S., \& Llorente, C. (2013). Preschool teachers can use a PBS KIDS trasmedia curriculum supplement to support young children's mathematics learning: results of a randomized controlled trial. A report to the CPB-PBS Ready To Learn Initiative. Waltham, MA, and Menlo Park, CA.

[25] PBS (2003). The digital classroom project: final report and recommendations. Alexandria, VA: PBS.

[26] Penuel, W. R., Pasnik, S., Bates, L., Townsend, E., Gallagher, L. P., Llorente, C., Naomi, H. (2009). Summative evaluation of the ready to learn initiative: preschool teachers can use a media-rich curriculum to prepare low-income children for school success: results of a randomized controlled trial. New York and Melno Park, CA: Education Development Center, Inc., and SRI International.

[27] Raudenbush, S. W. (2009). The Brown legacy and the O'Connor challenge: Transforming schools in the images of children's potential. Educational Researcher, 38(3), 169-180.

[28] Reed, R. (2003). Streaming Technology Improves Student Achievement. T H E Journal, 30(7), 14-20.

[29] Riley, R., Holleman, F., \& Roberts, L. (1999). Elearning: putting a world-class education at the fingertips of all children. U.S. Education Department's office of Educational Technology. Washington, D.C.
[30] Ross, J. L., \& Schulz, R. A. (1999). Using the world wide web to accommodate diverse learning styles. College Teaching , 47(4), 123-29.

[31] Sarama, J., \& Clements, D. H. (2009). Early childhood mathematics education research: Learning trajectories for young children. New York: Routledge.

[32] Smarty Pants. (2014). Parents overwhelmingly agree no other media brand meets their children's school readiness needs like PBS kids. Retrieved on February 10, 2015 from http://www.pbs.org/about/news/ archive/2014/new-survey/

[33] Syed, M.R. (2001). Diminishing the distance in distance education. IEEE Multimedia, 8(3), 18-21.

[34] Walma van der Molen, J., \& van der Voort, T. (2000). Children's and adult's recall of television and print news in children's and adult news formats. Communication Research, 27(2), 132-160.

[35] Weiland, C., Wolfe, C.B., Hurwitz, M., Clements, D., Sarama, J., \& Yoshikawa, H. (2012). Early mathemtics assessment: validation of the short form of a prekindergarten and kindergarten mathematics measure. Educationa Psychology, 32(2), 311-333. 